\title{
ОСИРОТЕЛ ЭКСИТОННЫЙ МИР. ПАМЯТИ АКАДЕМИКА СВЯТОСЛАВА МОСКАЛЕНКО
}

\author{
М. К. Болога \\ Институт прикладной физики, \\ 2. Кишинев, MD-2028, Молдова, е-mail: mbologa35@gmail.com \\ https://doi.org/10.52577/eom.2022.58.1.101
}

Перелистывая страницы совместной работы пятидесятивосьмилетней продолжительности в Институте прикладной физики, охватывают чувства гордости и благодарности, что посчастливилось пройти долгий профессиональный и жизненный путь рядом с Всеволодом и Святославом Москаленко, академиками, профессорами, лауреатами высших наград, премий и признаний, создателями школы теоретической физики в Молдове. Это ученые высокого долга и яркого таланта, огромного трудолюбия и безупречной честности. Их отличала беспредельная верность и преданность науке, призванию ученого, особая вдумчивость и основательность, твердость характера и щедрость, решительность и доступность, глубина чувств и доброжелательность. Они всегда вселяли веру в будущее. Их жизнь - яркий образец служения науке! Честь им и благодарность, таких ученых будем чтить всегда!

При изложении этих мыслей и переживаний переполняют эмоции от осознания того, что их хорошо знал, и возникает великая грусть о их утрате. Являясь пожизненным коллегой и практически в период той же продолжительности, заботясь о журнале нашего института, подготовил публикации о каждом брате-близнеце-академике. При этой утрате, при этом прощании единственной возможностью было увидеть и представить их вместе, как это было на протяжении всей жизни. Искренне признателен и подчеркиваю это с особым уважением и благодарностью за проделанную ими работу, за любовь и преданность исследованиям, замечательные черты характера. Они привнесли профессионализм, любовь к науке, доброту, безмятежность. Иметь бы по больше ученых масштаба Москаленко, и, интересно, будут ли когда-нибудь у нас два брата-близнеца-профессора, академики, основатели научного направления, в нашем случае - теоретической физики в Молдове?

Проходим через события и условия, определяемые временем, когда приоритетами являются жизнь, здоровье, профессионализм. В таких ситуациях становится виднее и яснее роль образования, культуры, науки и инновационных достижений, которые все уверенее и нагляднее определяют настоящее и будущее цивилизации. Анализируя рассматриваемую область, видишь, что в чувствах ушедших в вечность академиков и продолжающих активную жизнь исследователей нет ничего прекраснее научной деятельности.

Они всегда прислушивались к просьбам и нуждам коллег и делились своими профессиональными дарованиями. Мы полностью осознаем, что интенсивность жизни и эффективность деятельности имеют очень важное значение. Братьям Москаленко сопутствовало полное совпадение этих критериев, этих требований и возраста, поскольку была создана и обеспечена основательная теоретическая база исследований, их качество и значимость. Исследовательская жизнь коллег вызывает большие чувства, мы можем и должны гордиться тем, что было. Давайте сохраним радости прошлого и надеяться, что будущее не умалит ценности и значимости ученых Москаленко.

Чтобы представить себе величие и масштабы наших коллег, нужно было их увидеть, познакомиться, обменяться мнениями и остаться под ярким впечатлением. Свой авторитет и профессиональное доверие, свою признательность они заслужили фундаментальными работами, существенными результатами и делами, которые их индивидуализируют, возвышают. Благодарность есть память души и следует предложить частичку себя этим личностям, увидеть положительную сторону и возможный негативизм превратить в позитивизм. Они были образцом жизни, будущего. Они дали результаты огромного творческого труда, которые тронули сердца специалистов разных стран. Давайте продвинемся, поднимемся до их уровня и сохраним самые эмоциональные воспоминания.

Силой, светом, надеждой следует сохранить традиции, атмосферу спокойствия и творчества, мудрости и доброты, свойственные нашим коллегам, чтобы нас сопровождала глубина чувств и воспоминаний о другом, о их времени. Было бы хорошо, и поэтому призываю вернуться к годам, прожитым вместе, вести диалог поколений, чтобы коллеги, особенно преемники, были восприим-

(С Болога М.К., Электронная обработка материалов, 2022, 58(1), 101-113. 
чивы к научному опыту и наследию, не теряли бы событий, добрых дел, их смысл, анализировали их достоверность, сравнивали с настоящими достижениями, не забывая их, не сожалея о них.

Красивые и богатые душой люди искали научного чуда, верили в чудеса, и ожидания сбывались. Проникнемся академической ностальгией и, если позволит время, осуществим наши надежды, чтобы нас сопровождала оригинальность во имя наших дорогих коллег, ушедших по дороге невозвратной, в вечность. Вернемся снова к консолидации, вместе и деятельность эффективнее, и время краше, и на душе теплее. Мы прошли с нашими коллегами сквозь годы и времена, у них была впечатляющая жизнь, и нужно идти вперед, двигаться дальше, иметь удовольствие знакомиться с результатами наших потомков. Научная работа - это постоянный процесс, исследователь наделен даром творчества, и, надеемся, наши продолжатели достигнут других высот, других горизонтов. Пусть их воодушевят мудрость и простота академиков Москаленко, мы им безгранично благодарны, любим и помним.

Наука - это зеркало общества, лицо страны, ее надо поддерживать, продвигать, результаты всегда ожидаемы, труднодостижимы и реализуемы, и это было бы праздником не только для ее служителей. Эти убеждения были сутью, кредом деятельности наших коллег, они были уверены, что исследования помогут нам добиться того, чего желаем, быть там, где этого заслуживаем. Творческая и душевная гармония их вдохновляла, считали, что долг исследователя - быть эффективнее, выше, конкурентнее. Утверждали, что, где усилия, старания и труд, там и результаты, и они облагораживают моменты успеха и счастья. Важно получать поддержку, самим помогать и добиваться новых результатов. Необходимо знать ошибки прошлого, исправлять ошибки настоящего, чтобы не повторять их, желая нам новых достижений, надежд, вдохновения.

Нелегко писать о выдающихся людях, следует благодарить их за то, что они есть, академики Москаленко были великие личности, и мы были счастливы работать вместе. Наука имеет свою специфику и законы, которые мы должны усвоить, усовершенствовать и продвигать. Давайте держать науку на ладони, и она поддержит нас, необходимо моделировать настоящее и будущее с большой гибкостью, самоотверженностью и полнотой. И очень важно не только мечтать о будущем, необходимо его создавать.

В беседах, при каждом подходящем случае, Святослав Анатольевич касался жизненного пути брата и подчеркивал, что он был лидером теоретической и математической физики в Республике Молдова. Отмечал, что после окончания с отличием в 1951 г. физико-математического факультета Кишиневского государственного университета (КГУ) Всеволод Москаленко как самый выдающийся выпускник был оставлен в университете, где работал в должности ассистента. Вел занятия по теоретической физике и самостоятельно занимался теорией поляронов. Решающее значение в научной жизни имело его знакомство с работами школы выдающегося физика-теоретика и математика Н.Н. Боголюбова и его непреодолимая тяга к этой великой школе, созданной в Московском государственном университете им. М.В. Ломоносова и в Математическом институте им. В.А. Стеклова АН СССР. Как молодой перспективный физик-теоретик Всеволод Москаленко в 1958-1959 гг. был направлен на двухлетнюю стажировку в Москву, где влился в коллектив, возглавляемый академиком Н.Н. Боголюбовым, имея уже опыт самостоятельной научной работы. Усилия Всеволода Анатольевича оказались вознагражденными тем, что он оказался в звездные для теории сверхпроводимости годы (1957-1959) в Москве, где обсуждались вопросы, близкие к теории поляронов и биполяронов, которыми он занимался в Кишиневе. На семинаре, руководимом Н.Н. Боголюбовым, была поставлена задача обобщения теории сверхпроводимости Бардина, Купера и Шриффера (БКШ) на случай реальных сверхпроводников с перекрывающимися энергетическими зонами. Она была решена В.А. Москаленко в 1958 году в возрасте 30 лет, стажером-исследователем из КГУ. До сих пор не знаю, как это произошло и уже никогда не узнаю, но ему удалось решить эту задачу, и к 1 октября 1958 г. работа поступила в печать. Она оказалась настолько важной, что на ее основе он защитил в 1959 году кандидатскую, а в 1967 году докторскую диссертацию. В настоящее время двухзонная или более общая многозонная теория сверхпроводимости, разработанная 
Всеволодом Анатольевичем в 1958 году, стала классической. На ее основе, в процессе развития и обобщения, в Молдове возникла самостоятельная научная школа, возглавляемая профессором, доктором хабилитат физико-математических наук М.Е. Палистрантом.

Всеволод Анатольевич Москаленко перенял и развил лучшие научные традиции выдающейся научной школы академика Н.Н. Боголюбова. За 60 лет работы создал в Республике Молдова научную школу по теоретической и математической физике.

Немного о себе написал и Всеволод Анатольевич по случаю восьмидесятилетия. Родился 26 сентября 1928 г. в селе Бравича Оргеевского уезда Бессарабии (тогда Румыния, сейчас это Каларашский район Республики Молдова), молдованин, гражданин Республики Молдова.

Родители: отец, Москаленко Анатолий Емильянович, 1900 года рождения, и мать, Наталья Карабетовна, 1906 года рождения. Отец работал мелким служащим и учителем, а мать была домохозяйкой, затем учительницей. В 1940 г. при советской власти отец был репрессирован и погиб в ГУЛАГе. Мать при помощи сестер отца и своей сестры вырастила нас, двух братьев-близнецов. Мать умерла 21 ноября 1999 г. Брат Святослав во многом разделил мою судьбу.

В 1946 г. я поступил на первый курс физико-математического факультета Кишиневского госуниверситета (КГУ), открывшегося в том же году, который окончил с отличием в 1951 г. С сентября 1957 по май 1959 г. проходил аспирантуру в МГУ им. М.В. Ломоносова под руководством академика Н.Н. Боголюбова, а в мае 1959 г. защитил кандидатскую диссертацию в Математическом институте им. В. А. Стеклова АН СССР в Москве.

Десять лет занимался преподавательской деятельностью в КГУ, а с января 1961 г. работаю в Академии наук Молдовы: сначала в должности зав. отделом теоретической физики Института физики и математики, затем зав. отделом Института математики и, наконец, зав. отделом статистической физики и теории ядра Института прикладной физики АН Республики Молдова.

В 1964-1966 гг. проходил докторантуру в МГУ им. М.В. Ломоносова под руководством академика Н.Н. Боголюбова, и в ноябре 1967 г. защитил докторскую диссертацию в Математическом институте им. В.А. Стеклова. В 1971 г. мне было присвоено звание профессора по теоретической и математической физике. В 1970 г. был избран членом-корреспондентом АН Молдовы, а в 1976 г. - действительным членом, в обоих случаях единогласно.

В 1950 г. женился на Элеоноре Васильевне Попа 1925 года рождения, имею двух дочерей: Татьяну, 1953 года рождения, и Веронику, 1955 года рождения. В настоящее время Татьяна директор филиала Научно-исследовательского института ядерной физики МГУ в г. Дубна Московской области, а Вероника работает научным сотрудником в Институте сверхчистых веществ в г. Нижний Новгород. У меня четверо внуков и одна правнучка.

В 1970 г. я создал вторую семью. Моя вторая жена Москаленко Тамара Петровна (1938 года рождения) после тяжелой болезни скончалась 16 декабря 1995 г.

Основную научную деятельность сочетал с выполнением различных обязанностей, таких как член проблемных советов Президиума АН СССР по теории твердого тела и физике низких температур, член Президиума АН Молдовы (1990-1996 гг.), организатор Всесоюзной конференции по физике низких температур (Кишинев, 1982 г.). Был председателем научного общества учащихся «Вииторул» и советов по защите кандидатских и докторских диссертаций. С 1991 по 2004 г. являлся полномочным представителем правительства Республики Молдова в ОИЯИ. С 1 июля 1996 г. по настоящее время работаю по контракту в Лаборатории теоретической физики ОИЯИ в качестве главного научного сотрудника.

В 1980 г. мне была присуждена Государственная премия Молдовы по науке и технике. В 1981 г. награжден орденом «Знак Почета», в 1996 г. - высшей государственной наградой Молдовы Орденом Республики. С 2002 г. являюсь заслуженным деятелем Республики Молдова.

В 1990 г. кратковременно и в 1992-1993 гг. в течение полугода работал приглашенным профессором в Чанчуньском Северо-Восточном университете Китая. В 1997-2008 гг. имел гранты в рамках программы «Гейзенберг-Ландау» для сотрудничества с отделом теоретической физики Универ- 
ситета Дуйсбурга-Эссена. С 1999 г. по настоящее время сотрудничаю с Институтом теоретической физики Университета Салерно. В 1989-1993 гг. был членом редколлегии журнала «Теоретическая и математическая физика», с 1994 г. - член редколлегии «Romanian Journal of Physics».

Мною опубликовано более 400 научных статей в профильных журналах и шесть монографий по теории сверхпроводимости и спиновым стеклам. Всеволод Москаленко, 2008 г. (Электронная обработка материалов 2018, 54(4)).

Автор убежден, что они равноценные исследователи, абсолютно родные люди, олицетворяющие наш Институт. Всеволода Анатольевича я полюбил со студенческой скамьи и восторгался его ответственностью, пунктуальностью, трудолюбием. Они по-своему расставляли акценты, всегда удачно и обоснованно им удавалось предпринять пионерские исследования и достичь значимых результатов. Автор высоко ценил достижения коллег, озвучивал их результаты и делал это, зная, что похвала не лучший друг. Приятно, что это происходило в лучшие наши годы, будучи директором Института. Эмоции, безусловно, сильные, ведь наши коллеги - легенды, послы теоретической физики, развиваемой в Молдове, и никогда не было сомнений в их успехе и таланте. В этом великая сила исследовательской деятельности, специфика науки, что всегда радовало и радует.

Полагаю, уместно коснуться двух знаменательных дат, звездных дней наших коллег, - это девяносто- и восьмидесяти пятилетие, которые пока единичны в ИПФ, и очень желательно, чтобы они были намного чаще. Научные конференции, манифестации и мероприятия объединяют людей, сближают души, стимулируют активность и творчество.

Для широких кругов представителей физических наук девяностолетие братьев-близнецов (2018 год) останется знаменательной вехой, в том числе и в связи с проведением очередной девятой конференции по материаловедению и физике конденсатной среды, посвященной юбилею наших коллег. Участники более чем из 20 стран стоя приветствовали юбиляра - Святослава Москаленко. А аплодисменты - искренняя признательность и благодарность создателю теории экситонов и биэкситонов большой плотности, принесшей как ему, так и институту заслуженные славу и известность. К конференции было подготовлено юбилейное издание «Академикам Всеволоду и Святославу Москаленко 90 лет» (вкл. 1, кадр 1-1, нумерация слева направо и сверху вниз), в котором читатели ознакомятся с основными этапами жизненного пути, научными поисками и достижениями юбиляров, что впечатляет и вызывает чувство восхищения. Жизнь, отданная науке, наградила их судьбой быть и оставаться значимыми личностями в современной физике.

После восторженных поздравлений впечатлил доклад юбиляра, который традиционно отличался новыми достижениями, смелостью идей, фейерверком уравнений и формул. Председатель Оргкомитета академик Леонид Кулюк, открывая конференцию (вкл. 1, кадр 1-2), подчеркнул огромный вклад ученых Святослава и Всеволода Москаленко в деятельность Института прикладной физики. Отметил, что, к сожалению, академика Всеволода Москаленко не стало в апреле этого года, а в прошлом году оставил нас еще один титан в области физических наук, академик Валерий Канцер (Электронная обработка материалов 2020, 56(2)). Председательствующий попросил участников почтить минутой молчания память уважаемых ученых (вкл. 1, кадр 2-2). Ныне президент Академии наук академик Ион Тигиняну от имени руководства Академии наградил юбиляра медалью «Meritul științific» (вкл. 1, кадр 1-3) за резонансные, фундаментальные достижения. Подчеркнув важность конференции, отметил, что 90-летие со дня рождения братьев Москаленко, которые создавали историю науки, событие не только для Республики Молдова, но и международного масштаба. Директор института доктор хабилитат Михай Маковей выступил с докладом «Институт прикладной физики и знаменитые личности: Москаленко» (вкл. 1, кадр 2-1).

В ответной речи академик Святослав Москаленко подчеркнул: «Я хотел бы выразить благодарность всем участникам. Рад, что вы почтили меня и моего брата. Это прекрасное событие в моей жизни. Мы работали вместе всю жизнь, и делали все возможное, чтобы совершать хорошие дела. К сожалению, моего брата сегодня нет, он был настоящим лидером, более известным и открытым для научного сотрудничества». Затем юбиляр представил доклад «Двумерные пара-, орто- и 

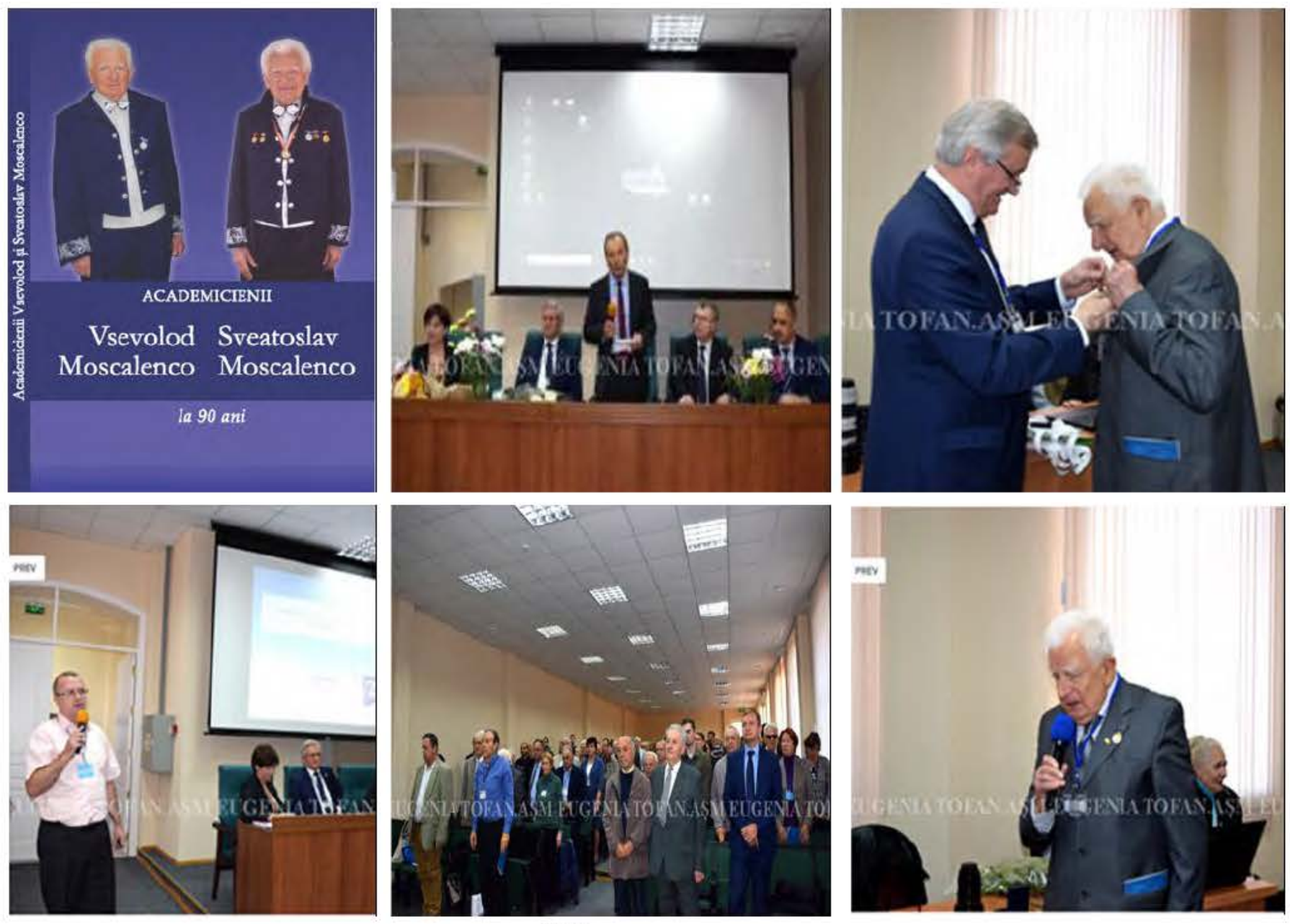

\section{5-летие}

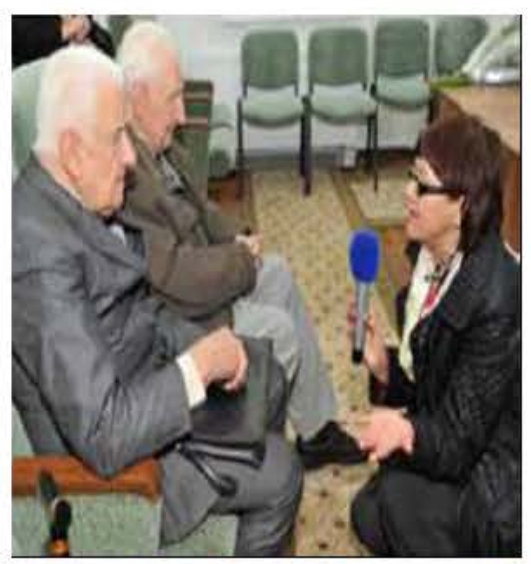

Seminarul ştiinţific dedicat aniversării a 85-a a academicienilor Sveatoslav şi Vsevolod Moscalenco.

"Probleme fundamentale ale materiei condensate", 26 сентября 2013 года
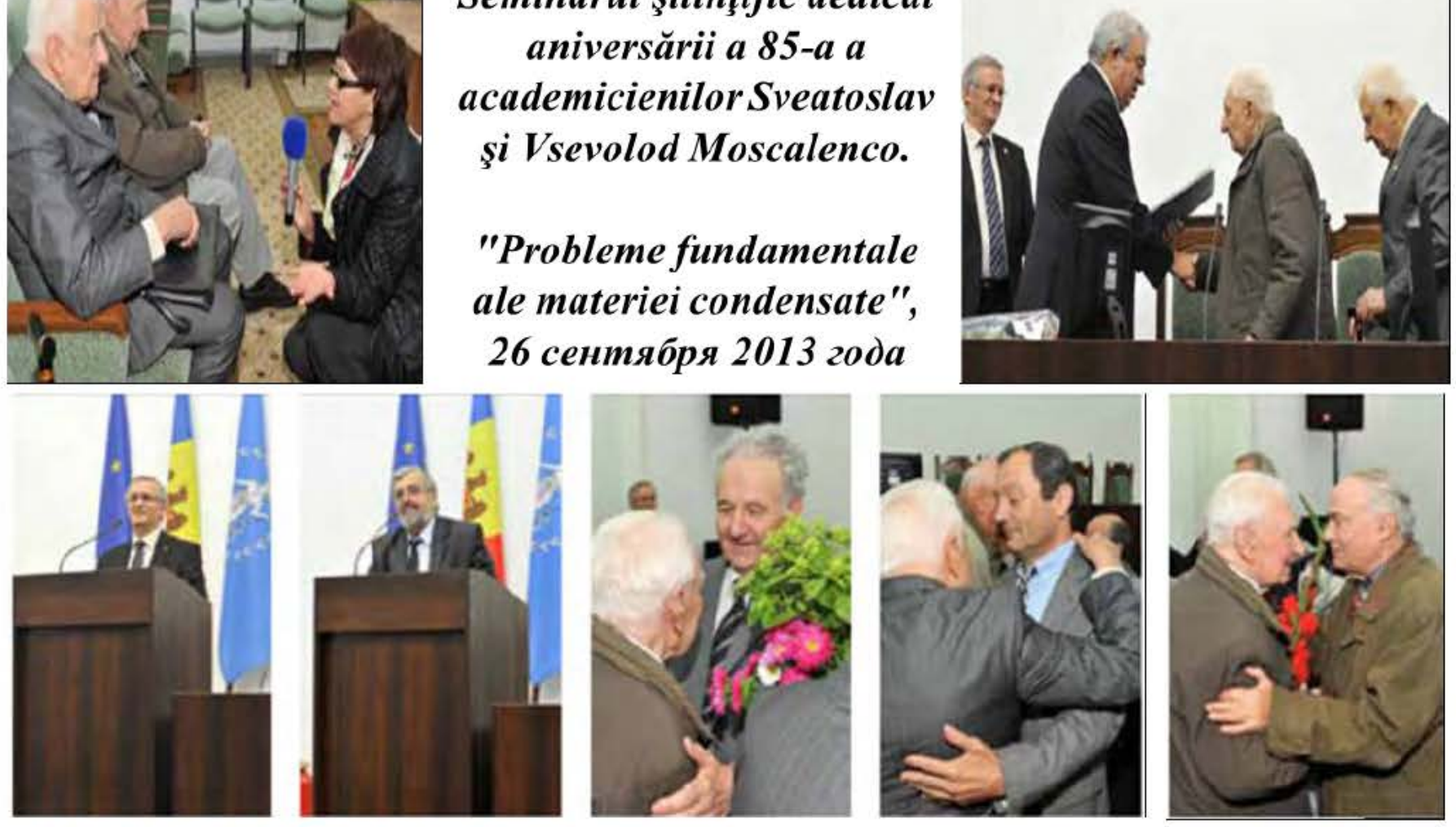

Вкладыи - 1 

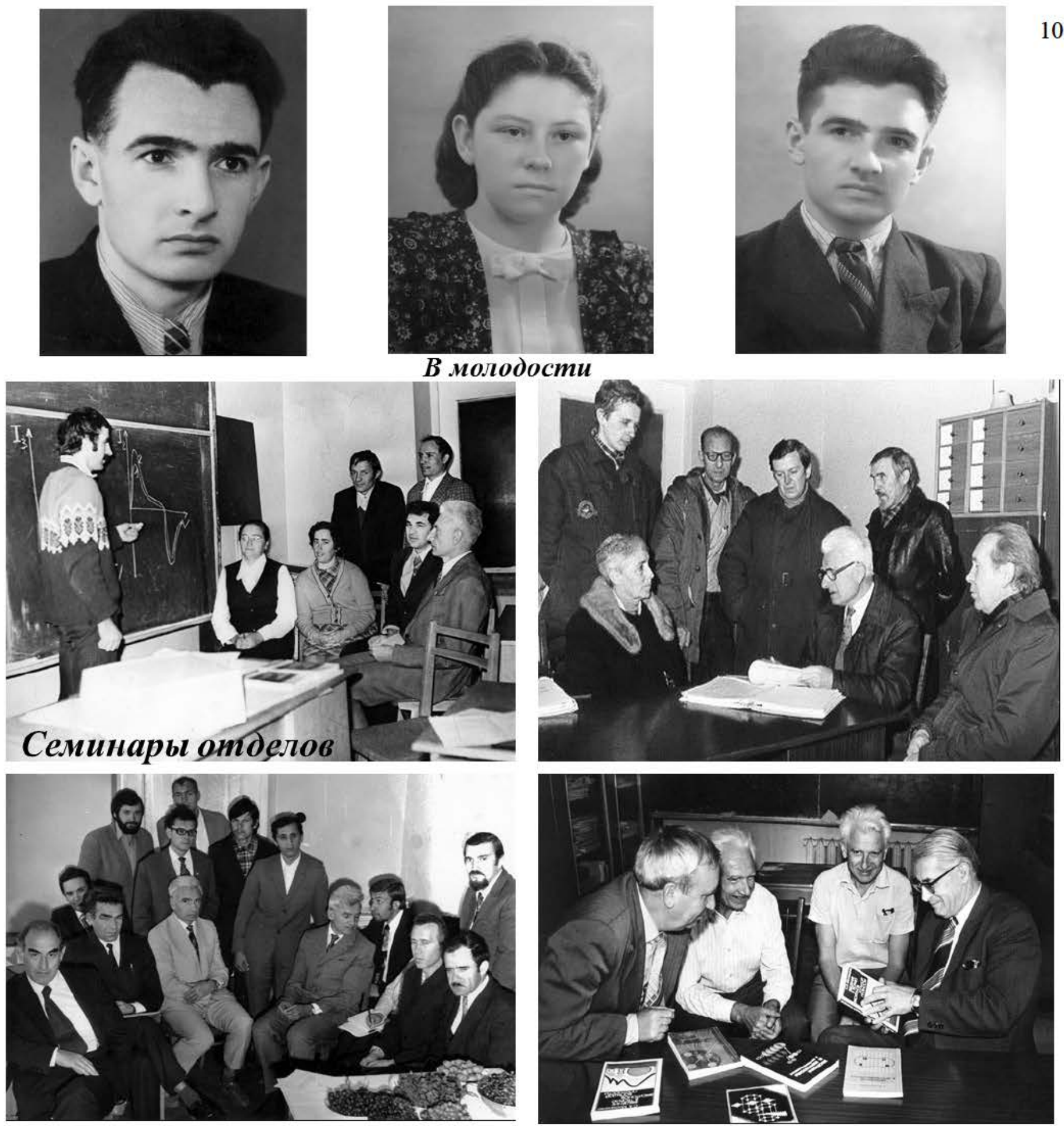

Аакадемики В.Л. Гинзбург и Л.В. Келдыи на

Академик Д.В. Гииу и президент Словакикой АН Г. Гайко
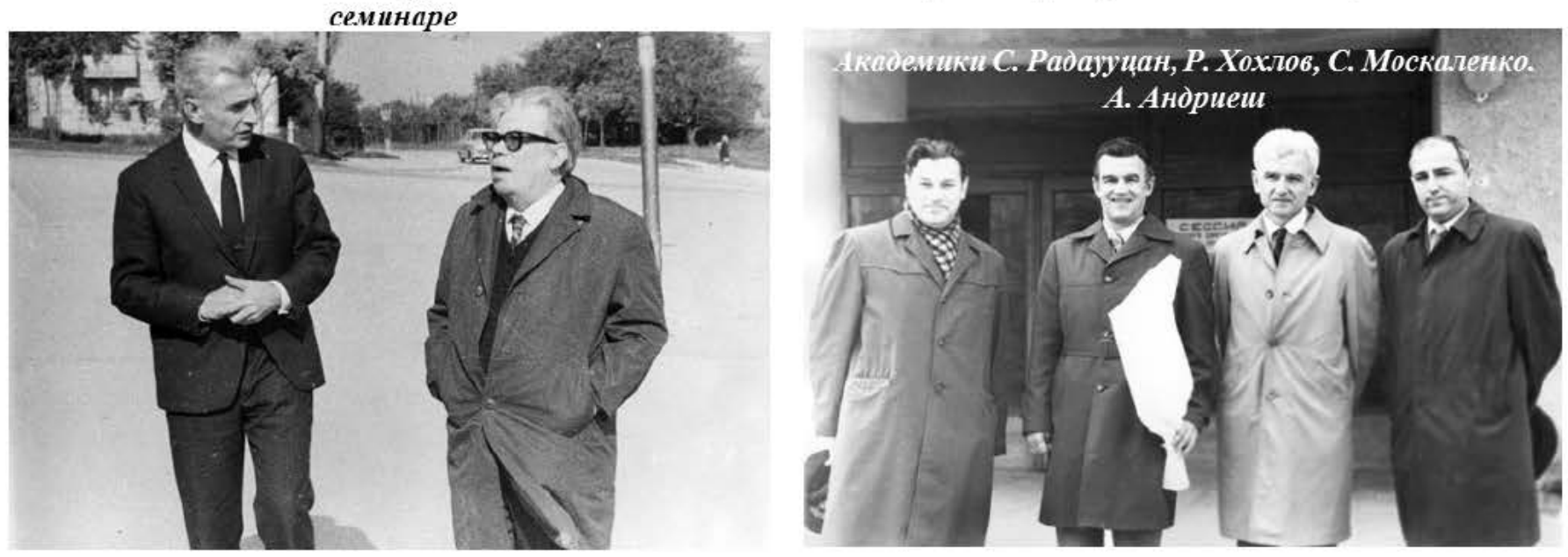


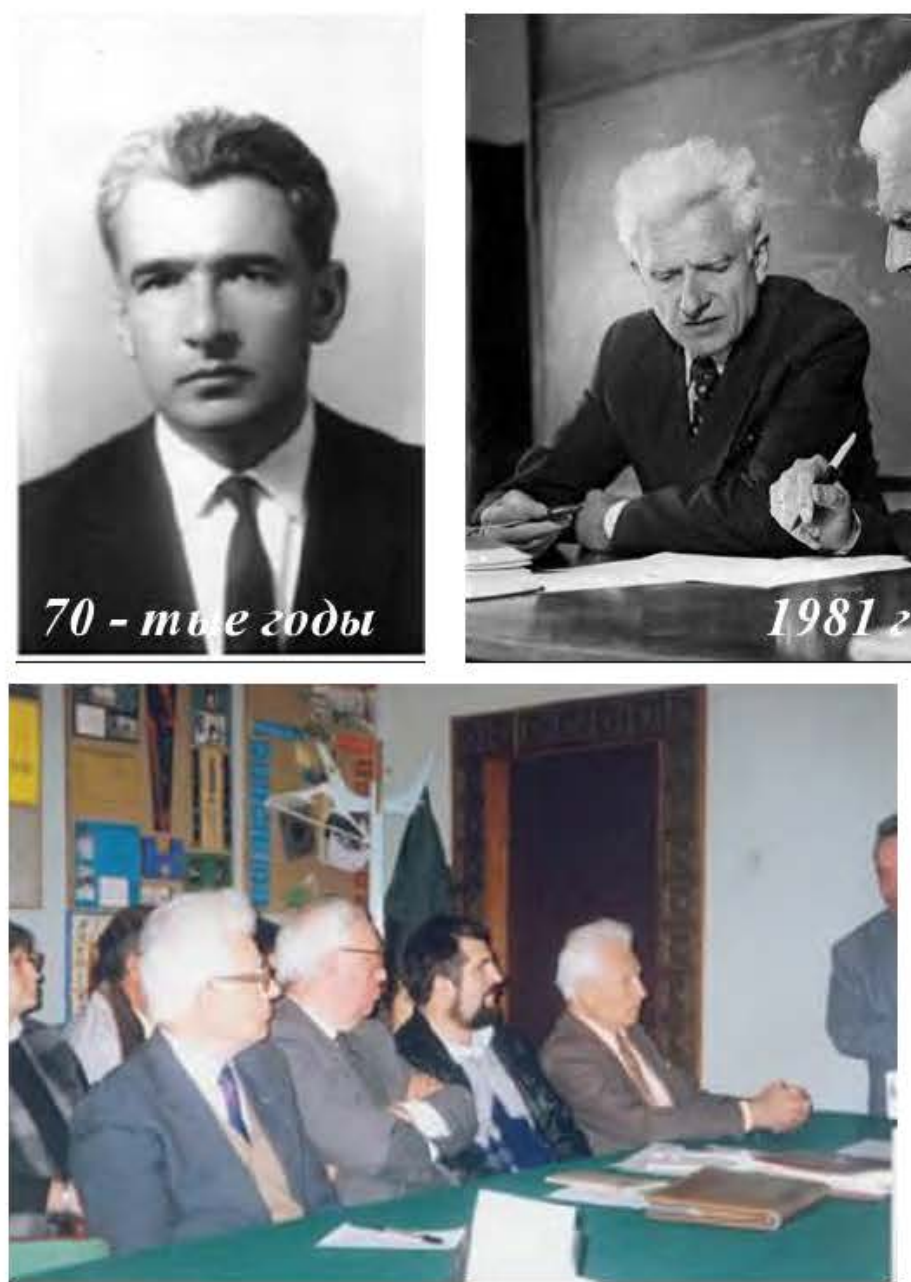

\section{Ученый совет ИПФ}

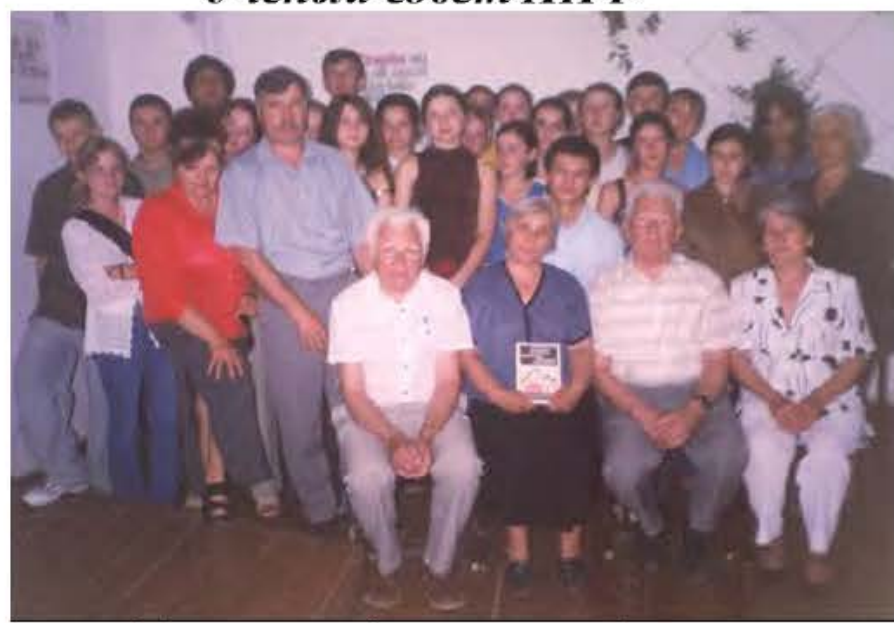

В лицее родного села Бравича

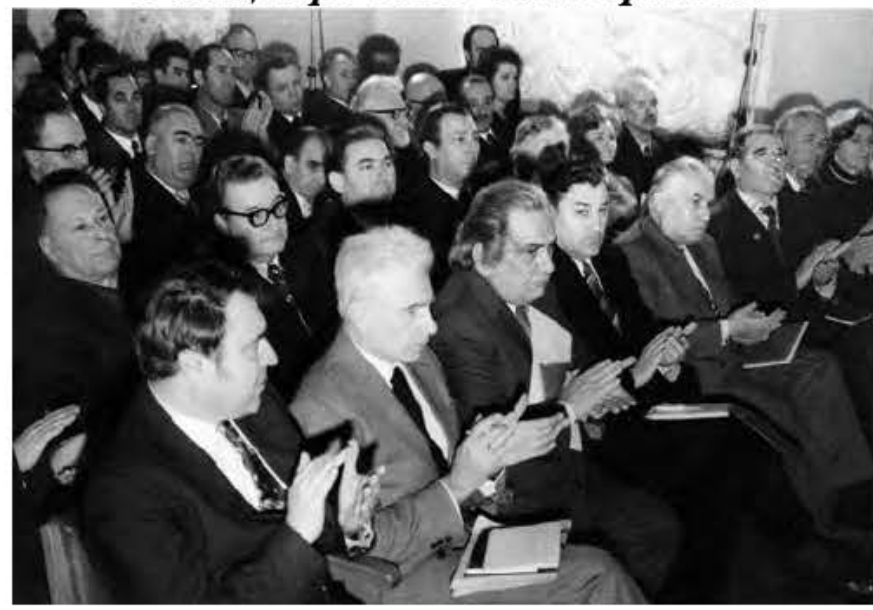

Общее собрание Академии наук
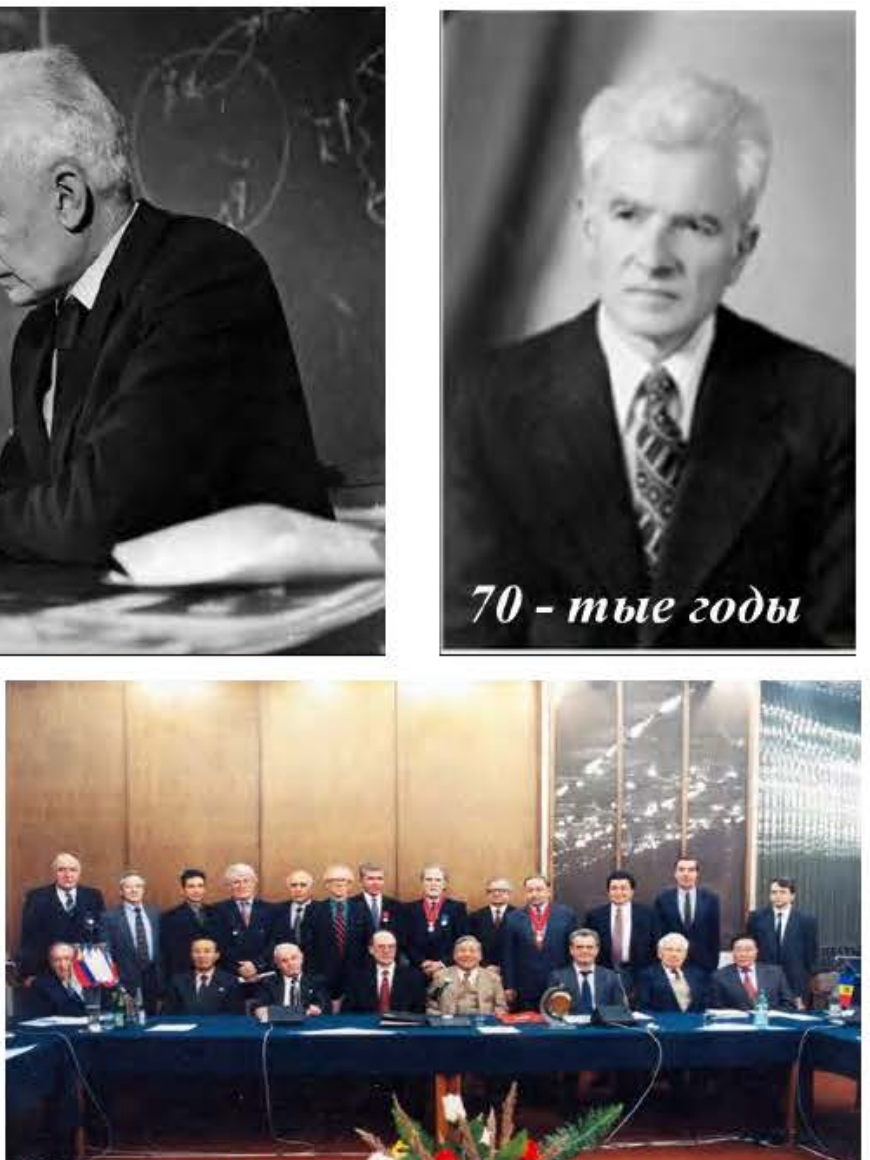

Комитет Полномочных Прецсиавителей оияи, г. Дубна, $80-c$ 2. ग
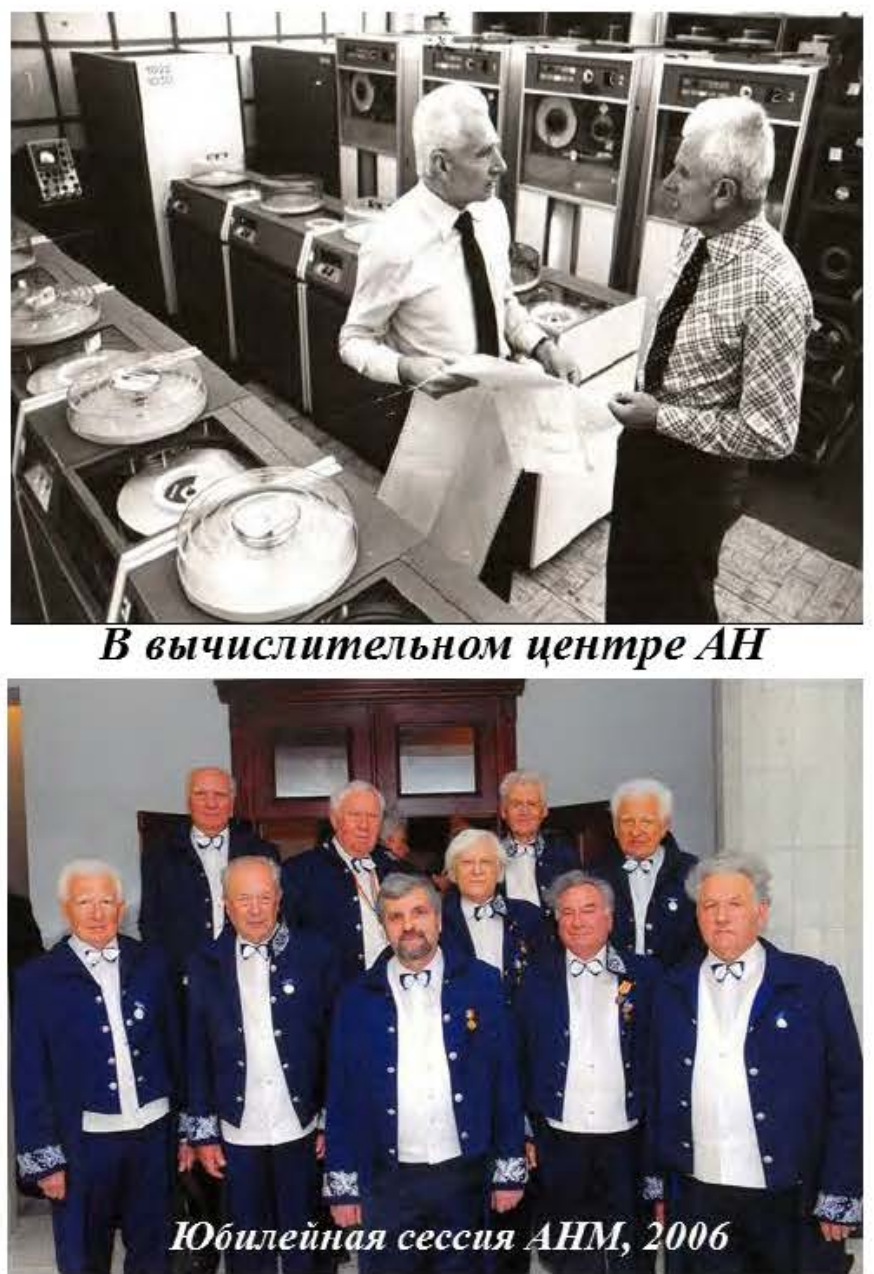

Вкладыци - 3 

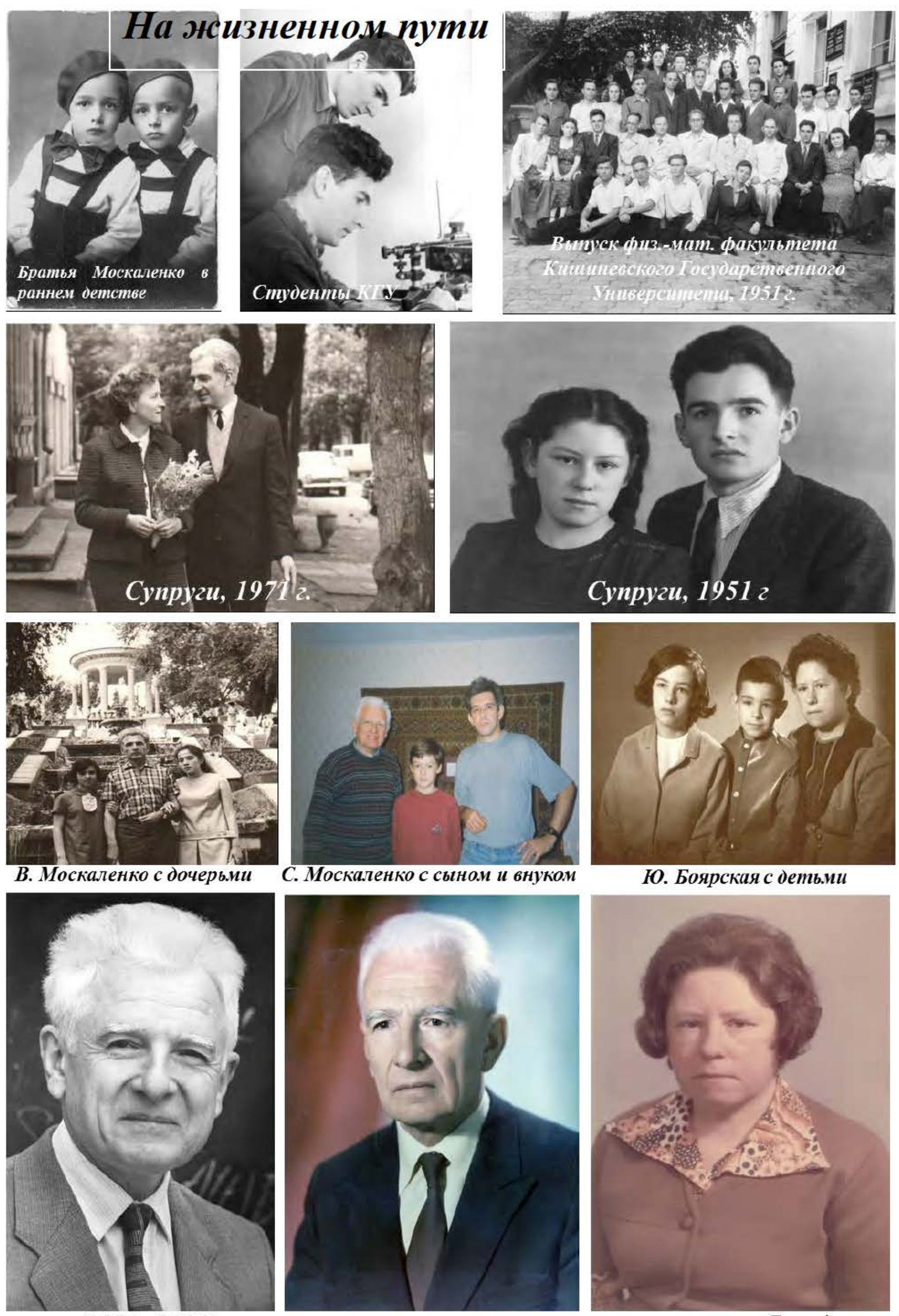

(1928-2022)

(1928-2018) 
би-магнитоэкситоны, взаимодействующие с квантовыми точечными вихрями» (вкл. 1, кадр 2-3). Вопросы, ответы, трогательные поздравления, непрерывный поток цветов, слова признательности и пожеланий юбиляру, доброжелательность и чувства причастности, безусловно, запомнятся надолго. На просьбу автора юбиляр отозвался краткой информацией о пройденном жизненном пути, которая, безусловно, впечатляет. Отметил, что в журналах «Электронная обработка материалов» (ЭОМ), издаваемом Институтом прикладной физики (ИПФ), и «Академос», издаваемом Президиумом Академии наук Молдовы (AНM), печатаются материалы о жизни и деятельности выдающихся сотрудников ИПФ и АНМ, включая статьи в память академика Всеволода Анатольевича Москаленко, профессора Юлии Станиславовны Боярской, профессора Петра Ивановича Хаджи, которые особенно мне дороги. Неоценимый бескорыстный труд по подготовке и печатанию многих материалов принадлежит академику Мирче Кирилловичу Бологе. Следуя его примеру, хотел бы написать несколько слов о работе в ИПФ, в котором непрерывно тружусь как вол, который тянет повозку в гору, с момента основания института в 1964 году уже более 50 лет практически в той же должности, за тем же столом и у того же окна. Кстати, это огромное преимущество нашей организации труда перед перемещением по горизонтали через каждые 2-3 года, практикуемое на западе. Но наша институционная система оправдана, если развиваемая в данном случае мною тематика подхвачена и в других лабораториях мира и развивается быстрее, чем я успеваю за ней угнаться. В случае стагнации продолжение работы не оправдано. Должен быть непрерывный прогресс.

Основателем и первым директором ИПФ был академик Борис Романович Лазаренко - первооткрыватель метода электроискрового легирования и электроискровой обработки материалов, который широко используется во всем мире. Первыми заведующими лабораториями и отделами стали выпускники Кишиневского государственного университета и Политехнического института (ныне Технический университет Молдовы).

Борис Романович Лазаренко был человеком с широким научным кругозором, без мелочной опеки, умел доверять, но проверять. Его характеризовали демократизм и благородство. И такую же обстановку он сумел создать в ИПФ, где велись жаркие споры и дискуссии, но в открытую и в определенных рамках.

В течение 15 лет под руководством Бориса Романовича произошел рывок в развитии физики в ИПФ, который успешно продолжался в последующие 18 лет под руководством академика Мирчи Кирилловича Бологи. Эти 30 с лишним лет составляют «золотой век» ИПФ, когда были созданы научные школы и достигнуты научные результаты, получившие признание в нашей стране и за рубежом. ИПФ по праву считался головным институтом физики в Республике Молдова. И мы гордились этим. Более обстоятельный обзор развития физики в Республике Молдова за последние 70 лет опубликован в журналах «Академос» (№ 3, 2016) и «Fizica şi tehnologiile moderne» (vol. 16, № 1-2, 2018). Здесь я перечислю несколько выдающихся результатов, с которыми знаком ближе.

Была разработана многозонная теория сверхпроводимости, ставшая классической и востребованной после обнаружения высокотемпературной сверхпроводимости в соединениях MgB2. Эти работы инициированы академиком Всеволодом Москаленко, развиты и продолжаются профессором М.Е. Палистрантом. В научной школе, созданной академиком В. Москаленко, защищено 20 докторских диссертаций и пять диссертаций доктора хабилитат. Дочерняя научная школа, созданная профессором М.Е. Палистрантом, насчитывает семь защищенных докторских диссертаций.

Под руководством профессора Юлии Боярской разработана модель пластического течения материала по сходящимся и расходящимся плоскостям скольжения кристалла, объясняющая форму отпечатков и образования навалов при испытаниях на микротвердость. Обнаружен новый импульсный механизм развития пластической деформации в кристаллах. В научной школе, созданной профессором Ю.С. Боярской, было защищено девять докторских диссертаций и две диссертации доктора хабилитат.

Поскольку мой жизненный путь неразрывно связан с судьбой Юлии Станиславовны Боярской, я хотел бы сказать несколько слов в память о ней. Со студенческих лет нас связывало общее 
стремление к знаниям. Юлия Станиславовна превосходила меня в способностях и в жизненных принципах.

Во время нашей работы в Академии наук Молдовы ее отличала удивительная преданность науке. Микротвердость кристаллов была незавидной, мало изученной областью знаний, но она ее никогда не променяла бы на что-либо более простое и перспективное. Она сумела проникнуть в суть загромождений дислокации около отпечатков и постепенно превратила гадкого утенка, какой выглядела эта область физики прочности и пластичности в 1950-е годы, в прекрасного лебедя, то есть в область науки с четкими закономерностями, которыми специалисты восхищались. Я думаю, что достойное поведение в различных жизненных ситуациях было ее основополагающей чертой характера.

Я работал с профессором Петром Ивановичем Хаджи около 50 лет, начиная с его дипломной работы в начале 60-х годов, когда он был студентом Кишиневского госуниверситета, впоследствии, когда он был аспирантом, потом в составе отдела теории полупроводников и квантовой электроники ИПФ, где стал сотрудником, защитил кандидатскую диссертацию в 1968 и докторскую диссертацию в 1983 году. В последние 25 лет Петр Иванович сформировался как глава самостоятельной научной школы в рамках общей нашей тематики, сосредоточив свои усилия на проблемах когерентного нелинейного распространения лазерного излучения в экситонной области спектра кристаллов с участием когерентных экситонов и биэкситонов, на вопросах распространения световых сигналов в каплерах и световодах, а также волн материи в случае Бозе-эйнштейновской конденсации атомов и молекул при сверхнизких температурах, включая ультрахолодную и когерентную химию. Научная школа Петра Ивановича объединяет выпускников университетов с обоих берегов Днестра из Кишинева и Тирасполя - и насчитывает 19 докторских диссертаций. Опубликовано около 1500 научных работ и сообщений, шесть монографий и учебное пособие. Более подробное описание научного вклада Петра Ивановича в современную физику конденсированных сред и нелинейную оптику приведено в «Moldavian Journal of Physical Sciences» (vol. 17, № 1-2, 2018).

Сейчас в лаборатории теоретической физики работают представители четырех научных школ, включая школы академика Всеволода Москаленко, профессоров П.И. Хаджи и М.Е. Палистрант и мою. Мы все вместе в течение 50 лет работы подготовили 71 доктор наук и 10 докторов хабилитат, опубликовавших около 2500 работ и сообщений, издавших более 10 монографий, что эквивалентно работе небольшого института теоретической физики. Как видите, в течение последних 50 лет благодаря усилиям целой плеяды выдающихся ученых теоретическая физика в Республике Молдова вышла на высокий уровень, получив признание в нашей стране и за рубежом.

Несмотря на невзгоды, которые бывают у каждого человека, я считаю, что мне в жизни повезло. Повезло иметь таких преданных своей семье, самоотверженных родителей, которые отдали свои жизни, чтобы поднять нас, своих детей. Это Анатолий Емельянович и Наталья Карабетовна Москаленко. Повезло, что у меня был брат-близнец Всеволод, с которым у нас практически одна судьба до окончания университета и который был всегда рядом, когда мне что-то угрожало. Повезло встретить и жениться на Юлии Станиславовне Боярской, о которой писал выше. Я горжусь нашими детьми Еленой и Евгением.

Работаю в ИПФ АНМ уже 58 года (прим. автора), что само по себе является необыкновенной удачей, быть на одном месте и в одной должности, иметь замечательных и выдающихся коллег и сотрудников, таких как Петр Иванович Хаджи, о котором я писал выше. Это обстоятельство важно, потому что оно способствовало формированию, развитию и достижению основных результатов моей научной деятельности, которые можно охарактеризовать двумя явлениями: биэкситон и бозеэйнштеновская конденсация экситонов и биэкситонов. Наша выдающаяся сотрудница, доктор хабилитат физико-математических наук А.И. Бобрышева, которая работает ныне в Дортмунде в Германии, говорила в шутку, что у меня сын Биэкситон и дочь Бозе-эйнштейновская конденсация. Это достижение и общий итог были бы невозможны без неоценимой, решающей, благородной и 
бескорыстной помощи и участия выдающихся физиков современности, которых, к своему счастью, я встретил на своем пути. Святослав Москаленко (Электронная обработка материалов 2018, 54(6)).

Отражая пройденный путь, посвященный науке, в память о Святославе Анатольевиче подчеркну, что экситоны, биэкситоны и Бозе-эйнштейновская конденсация неизменно занимали главенствующие позиции в его научной судьбе, а академик оставался им верным и в них влюбленным.

Планы и мечты Святослава Москаленко впечатляли, их реализация в определенной степени становилась проблематичной, но надеялись, что и в создавшейся ситуации с состоянием здоровья неожиданности и волнения будут преодолены. Пройдет время, и мы сполна почувствуем атмосферу успехов и свершений его продолжателей и учеников. Надеемся, они останутся верными экситонам и Институту, и это будет лучшей памятью о своем руководителе. Учитель и ученики всегда были воодушевлены самыми значимыми начинаниями и достижениями, соответствовали самым высоким требованиям и критериям, и, безусловно, они это оправдают!

Будучи преданным теоретической физике, Святослав Анатольевич всегда делал то, что чувствовал, радовался тому, что успели совершить и предстояло сделать. Всегда содействовал успеху, воодушевлял коллег и продолжателей на напряженный труд в важной области знаний, был научным руководителем, вселял добрые надежды, оставался оптимистом, создавал творческую атмосферу. Всегда был верным и смелым борцом за успешное развитие фундаментальных исследований, радовался достигнутым результатам и особенно тем, которые желали достичь.

Его отличали высокие человеческие и душевные качества, объективная оценка результатов, бескорыстная помощь, передача знаний, обмен опытом. Особенно следует подчеркнуть не восприятие ненадежных результатов, мог согласиться с возможными неточностями, приветствовал старания найти и исправить ошибки, но никогда не допускал недостоверных результатов. Его отличали удивительное отношение к научной деятельности, верность науке, что создавало позитивную атмосферу, рождало энтузиазм, усиливало взаимную ответственность и обеспечивало совместное достижение новых успехов. Хорошо понимал, что завтрашний день требует новых знаний и ставит новые задачи, что жизнь обгоняет мечту, и важно жить свежими идеями, поскольку они наши надежды, а значит, и будущее. Был на твердых позициях, что качественные результаты заслуживают внимания и одобрения, а другие будут отменены жизнью и историей.

Жизнь отблагодарила Святослава Анатольевича за многолетний труд, за высокую требовательность к себе, за новизну и надежность генерированных результатов - был отмечен Государственной премией Советского Союза, которая считалась высшей наградой, кавалер Ордена Республики Молдова, стал известным и признанным широкими кругами научной общественности, и не только Европы, им всегда восхищались!

В год 85-летия патриархов науки - создателей и успешно развивающих теоретическую физику в ИПФ и Молдове академиков - братьев-близнецов Всеволода и Святослава Москаленко, автор отразил их творческий и жизненный путь в Институте прикладной физики (Электронная обработка материалов, №7, 2013) и в эмоциональных фотографиях, отражающих различные этапы жизни, которые вызывают ностальгию и прекрасные воспоминания. Ощущалась быстротечность времени, и казалось, что на днях, в день своего 80-летия, юбиляры вручили мне старательно оформленные издания (Academicianul V.A.Moscalenco la 80 ani bibliogr. Chişinâu, Konstantin Gudima, Leonid Dohotaru. - ch s.n., 2008, Elan Poligraf SRL Academicianul S.A.Moscalenco la 80 ani bibliogra / Petru Khadghi, Igor Belousov, Evghenii Dumanov, Igor Podlesnâi, Angela Ştefan - Ch. S.n., 2008, Elan Poligraf SRL. Пишу об этом, будучи уверен, что читатель найдет в них интересные сведения о двух гигантах теоретической физики.

Судьба наших коллег - буквально зеркальное отражение, а отношение к семье и детям сказочное. Святослава Анатольевича и Юлию Станиславовну всегда видели вместе, приходящими и уходящими из института; более того, они трудились в соседних комнатах. Был приятно удивлен, когда узнал, что по субботам в любую погоду Всеволод Анатольевич навещал супругу на центральном кладбище. Это замечательные черты характера талантливых, безгранично преданных 
своим близким и делу коллег. А об их благоговейном отношении к маме даже не приходится говорить (вкл. 4).

Памятная встреча в день восьмидесятипятилетия прошла в бывшем конференц-зале ИПФ с участием президента Академии наук академика Георгия Дуки и первого вице-президента академика Иона Тигиняну, самыми яркими эпитетами охарактеризовавших юбиляров.

Прослушали выступления именинников В.А. Москаленко («Диаграммная техника для системы сильно коррелированных электронов») и С.А. Москаленко («Бозе-эйнштейновский конденсат двумерных экситон-поляритонов в микрорезонаторах») и их воспитанников - профессоров М.Е. Палистранта («Вклад молдавских ученых в многозонную теорию сверхпроводимости»), П.Н. Хаджи («Бозе-эйнштейновский конденсат атомов и молекул и ультрахолодная когерентная суперхимия»), А.И. Касияна («Необычные транспортные свойства органических квазиодномерных кристаллов»), которые отразили значимые, импонирующие результаты десятилетий.

Размышляя по поводу хорошо продуманного и подготовленного семинара, приподнятого настроения коллег, учеников и участников торжественной атмосферы, подчеркну, что это была встреча с энциклопедистами и легендами теоретической физики Молдовы. Братья-академики, личности, чей вклад в науке признали авторитеты на разных параллелях и меридианах, на протяжении более 60 лет удивили новыми терминами, явлениями, механизмами, моделями. И снова задавал себе вопрос: повторится ли когда-нибудь подобный феномен в нашем благодатном крае?

Вручение юбилярам д.ф.-м.н. И. Холбаном, в прошлом сотрудник ИПФ, удачно названной книги “Doi brazi viguroşi ai fizicii basarabene” («Две мощные ели физики в Бессарабии»), добавило теплоты в приятную и добрую атмосферу семинара. Слова признательности юбилярам было нелегко подобрать и мне, знающему в то время братьев-академиков более 60 лет и относящегося к ним, коллегам по ИПФ, с особой любовью.

Их настойчивость, ясность, постоянные усилия приносили плоды благодаря тому, что в институте были благоприятные условия. От них исходили свет, профессионализм, доброта, безграничная любовь к исследованиям, душевное отношение к коллегам и профессионалам своего дела, интеллигентность, безмятежность. Они ждали чуда, и оно свершилось. Им сопутствовала одухотворенность и оригинальность, они руководствовались тем, чтобы одна деятельность была на пользу другой. Богатые профессионально и добрые люди (вкл. 2-4). Действительно, добро - это врожденный дар, его нельзя забывать и им никогда нельзя пренебрегать. Фундаментальные столпы, нам было кем гордиться. Они были те, за которыми шли, на которые равнялись и заслуживали восхищения коллег. У нас прекрасные результаты, у нас есть большое наследие, есть идеи, у нас есть что продвигать и развивать. С глубоким чувством и глубоким уважением, с любовью ко всему, что значили и будут означать наши коллеги - академики Святослав и Всеволод Москаленко. Пожертвуем тем, кто мы есть, чтобы стать теми, кем желаем быть. Давайте будем ближе к потребностям настоящего и возможностям будущего. Сохраним принципы и традиции солидарности. Рядом с высочайшим чувством мы ставим профессионализм, понимаем, что проблемы - это не признаки остановки - это ориентиры, а отношение - это маленькая вещь, которая имеет большое значение. Сейчас не время думать о том, чего не можем сделать, а о том, что делать с тем, что у нас есть.

В науке главное - летать, и важно иметь рядом коллег, которые все сделают и не дадут упасть. Такими проявили себя братья Москаленко. Они были на позициях, что личность жертвует собой, а не оправдываться и заслуженно будем ссылаться на легендарных физиков. Они оставили много хорошего, что мы должны достойно сохранить. Их страсть и талант шли рука об руку. К сожалению, мы не будем стучать в дверь, чтобы увидеть их снова. Мы будем часто просматривать их работы, возвращаться к воспоминаниям с тоской и теплыми чувствами. Остаемся на красивых тропах сверхпроводимости и экситонов. Они всемирно известные физики, и пожелаем им покоя с благословением. 
У них были глубокие исследования, результаты на все времена, высокие полеты, они принесли известность институту на весь мир, закончив свой жизненный путь. Восхищение и уважение, высшие оценки и признания. Сохранение и передача традиций - это жизненный урок и урок всей жизни. Это были известные, масштабные ученые, они заложили основу для многих людей. Их голоса будут услышаны среди ангелов. Есть моменты истории и традиции, и когда мы не можем изменить ситуацию, должны сами измениться. Не будем забывать - посеешь дело - пожнешь факт, посеешь факт - пожнешь характер, посеешь характер - пожнешь судьбу. Кто говорит, тот сеет, кто слушает - пожинает. Они успевали и одно и другое, были наделены доброжелательным характером, ободряющим вдохновением, добившись результатов от души и для души,

Пролистаем воспоминания и не забудем, если будем делать то, что делаем, станем успешными людьми. В исследованиях, в науке есть вещи, которые не видны, но без них не можем двигаться дальше. Исследователи не имеют возраста, они остаются душой юниоров, молодых людей, мечтателей, устремленных в будущее. Святослав и Всеволод Москаленко - имена, давно и прочно блиставшие и блистающие в научном мире. Вписали яркие страницы в теоретическую физику. Их работы - завещание, важнейшие вехи, освещают путь преемникам и многим продолжателям. Они отдали все и полностью себя. Если у Всеволода и Святослава Москаленко есть имя счастью, то это сверхпроводимость, экситоны и Бозе-эйнштейновская конденсация. Всегда стремились и брали новые высоты. Так же, как и они, будем стремиться к более ясным временам, надеяться на заслуженное будущее. Прошли через победы, испытания, иногда неудачи, и очень важно продолжить традиции ИПФ. Давайте передадим дальше плоды нашей работы, давайте станем конкурентоспособными. Будем благодарить судьбу за каждый успех, за каждую надежду, особенно когда они становятся драгоценными с точки зрения будущего.

Они создавали и писали историю теоретической физики, рождение которой по праву принадлежит братьям Москаленко. Их отличали удивительное отношение к научной деятельности, верность науке, что создавало позитивную атмосферу, рождало энтузиазм, усиливало взаимную ответственность и обеспечивало совместное достижение новых успехов. Быть заслуженным гражданином мира науки - неоценимая привилегия и ответственность, и это было их кредо. Вспоминая прошлое и анализируя настоящее ИПФ, высоко ценим, что деятельность академиков Святослава и Всеволода Москаленко находилась в предпочтениях физиков, они всегда знали, что и как делать. Путнику к лицу дорога, С. Москаленко - экситоны, В. Москаленко - сверхпроводимость, они олицетворяли идеал, который нужно беречь и к которому следует стремиться. Имплантировали продолжателям навыки адаптироваться и соответствовать требованиям настоящего и будущего, ориентироваться на перспективные направления, быть убежденными и уверенными, что станут успешными.

Позади беспокойные годы, длительный период поисков и находок, на протяжении которых единственными целями наших коллег были новизна и качество результатов. Это всегда было во главе угла, было стремлением и желанием достичь лучших результатов, углубления фундаментальных исследований. Жажда познания, проникновение в суть физических явлений, углубленный поиск являлись неизменными их спутниками.

Пробил час расставания, время ухода в воспоминаниях, и далее следует вечность. Мы осиротели, и искренне сохраним память об академиках Всеволоде и Святославе Москаленко, об интеллектуалах в общении, о доброжелательном отношении к людям и жизни.

Все мы ведомы мыслью и верой, что они вовсе не перестали жить, а просто их нет среди нас, будем чувствовать их присутствие, и они всегда будут жить в наших сердцах. 